Acta vet. scand. $1967,8,360-368$.

From the State Veterinary Serum Laboratory, Copenhagen, Denmark.

\title{
THE DIAGNOSIS OF PSEUDORABIES BY THE FLUORESCENT ANTIBODY TECHNIQUE
}

By

\author{
A. Meyling and V. Bitsch
}

The laboratory diagnosis of pseudorabies is usually based upon inoculation of rabbits and tissue cultures with tissue suspensions derived from the central nervous system and other organs of the suspected animals (9). Although these methods are reliable, the growing number of pseudorabies cases among Danish pigs justifies attempts to introduce more rapid and inexpensive diagnostic procedures.

Staining of pseudorabies virus by the fluorescent antibody technique (FA) has been described by Albrecht et al. (1). The virus was demonstrated in chick embryo cell cultures and in frozen sections of tissues from the central nervous system of experimentally infected pigs and rabbits.

The present communication briefly describes the use of FAstaining for the demonstration of pseudorabies virus in the brains of naturally infected piglets and evaluates the method as an aid to a rapid diagnosis of pseudorabies.

\section{MATERIALS AND METHODS}

Animals examined. Specimens were taken from 51 pigs submitted to this institute for pseudorabies examination. Most of these pigs had either died or been killed in an advanced stage of disease.

To set a reasonable limit to the study it was decided to confine the examination to the brain, from which sections were prepared and stained as described below. 
Serum and conjugate. Fluoresceinisothiocyanate (FITC) ${ }^{\star}$ ) labelled globulins were prepared from the serum of a sow immunized with the Danish pseudorabies strain Korsoer B/8 XII (2). The serum had a SN-titer of 1:256 when tested against 100 TCID50. Precipitation and conjugation of the globulins were performed as described by Cherry et al. (3) with the exception that the amount of fluorescein used $(0.025 \mathrm{mg} / \mathrm{mg}$ protein) was added to the globulin solution as a suspension in carbonate buffer $(0.05 \mathrm{M}, \mathrm{pH} 9.0)$. Unreacted fluorescein was removed by gel filtration on Sephadex G-25**) equilibrated with PBS (0.14 M-NaCl, $0.01{\mathrm{M}-P \mathrm{P}_{4}}_{\mathrm{pH}} \mathrm{pH}$ 7.3) (6). Before use the conjugate was absorbed with lyophilized pig kidney powder.

Sectioning. Tissue blocks were routinely cut from one half of the brain as follows:

1) One $2-3 \mathrm{~mm}$ thick block cut transversely at the top of one of the cerebral hemispheres, the landmark being the end of the marginal fissure.

2) One block cut sagittally through the vermis cerebelli.

3) One block cut transversely through the middle of the pons.

The blocks were frozen on tissue holders placed on pieces of dry ice. The frozen specimens were then stored in labelled plastic bags in the cryostat***) either for a few hours or overnight to equilibrate with the cryostat temperature $\left(-20^{\circ} \mathrm{C}\right)$. Sections were cut with the microtome set at $6 \mu$, picked up on warm slides and fixed in acetone at room temperature for $10 \mathrm{~min}$.

FA-staining. The most suitable working dilution of the conjugate (1:5) was determined by staining sections of brains of intracranially inoculated mice. Sections were flooded with this dilution and incubated in a moist chamber at $37^{\circ} \mathrm{C}$ for $1 / 2 \mathrm{hr}$. After 2 washings in PBS for $10 \mathrm{~min}$. the sections were mounted in glycerol buffered at $\mathrm{pH} 8$.

Tissue culture. Primary pig kidney cell cultures were prepared from kidneys of six-month-old swine and seeded in $14 \times 115 \mathrm{~mm}$ plastic tubes (Nunclon 51-12-2) ${ }^{\star \star \star \star}$ ). The growth medium was

*) Baltimore Biological Laboratories. inc, Md., Baltimore, USA.

**) Farmacia, Uppsala, Sweden.

***) International Equipment Co. model CTD.

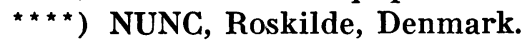


Hank's solution with $0.5 \%$ lactalbumin hydrolysate, $0.01 \%$ yeast extract, $15 \%$ calf serum, 100 i.u. penicillin and $0.1 \mathrm{mg}$ streptomycin pr. ml. Earle's solution with $2 \%$ calf serum and the above mentioned additives was used as maintenance medium.

Inoculation of tissue cultures and rabbits. Pieces of brain tissue were ground in a mortar with acid washed, sterile sand, and $10 \%$ suspensions were prepared in maintenance medium with 200 i.u. penicillin and $0.2 \mathrm{mg}$ streptomycin pr. $\mathrm{ml}$.

After centrifugation $0.2 \mathrm{ml}$ of the supernatant was inoculated into each of 6 tissue culture tubes including 3 to which had previously been added $0.2 \mathrm{ml}$ pseudorabies antiserum. The tubes were examined daily. A positive diagnosis was based on the finding of characteristic cytopathic changes that were neutralized by the immuneserum.

Rabbits were inoculated intramuscularly in the thigh with $1 \mathrm{ml}$ of the $10 \%$ brain tissue suspension.

Microscopy and photomicrography. The microscopical examination of the slides was performed with a Reichert Zethopan (Binolux) microscope equipped with a twin HB 200 mercury lamp and a $30 \mathrm{w}$ low voltage lamp. Usually dark ground microscopy was used with a BG $12 / 3 \mathrm{~mm}$ as a primary and OG4/1 mm as a secondary filter. This combination was very convenient for screening the preparations through binoculars. However, when positive cells were found the light path was shifted to the monotubus used for photomicrography and the filters were changed so as to provide a pure ultraviolet exciting illumination (UG $1 / 1.5 \mathrm{~mm}$ ) in combination with a colourless ultraviolet light absorbing secondary filter (GG13 + Wratten 2B). Photomicrographs were taken as colour transparencies using High Speed Ektachrome daylight film with exposure times from 1 to 2 min.

\section{RESULTS}

Distinct patterns of fluorescence were seen in the different parts of the brain. In the cerebrum primarily the neurons of the cortex were affected and at low power broad rows of fluorescent neurons were seen between the molecular layer and the white matter, where only scattered fluorescent cells were found (Fig. 1). In the cerebellum was a much more uneven distribution of the affected cells, and these were often arranged as fluorescent foci 


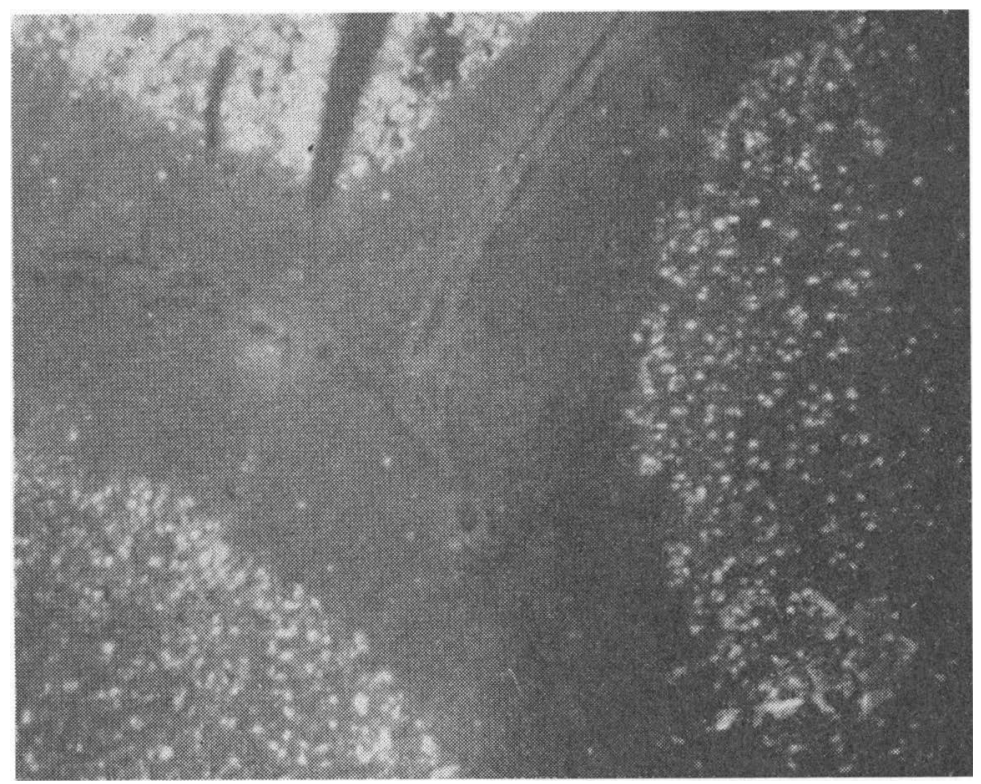

F i g u r e 1. Case no. 52. Section of the cerebral cortex. All the neurons involved. Brightground $\times 66$.

in the granular layer. Sometimes a few Purkinje cells were involved as part of such a focus, but a particular predeliction of the virus for these cells was not observed. In the pons there usually were a few fluorescent neurons, but sometimes no fluorescent cells could be found.

The intracellular distribution of fluorescence varied, and viral antigen was found in the cytoplasm as well as in the nucleus. The nuclear fluorescence was generally less pronounced than that of the cytoplasm and was often seen as fluorescent dust or small granula.

In a few cases intranuclear inclusions of the size of Cowdry type A bodies were found. Their shape, however, was more irregular than in conventionally fixed and stained preparations.

The cytoplasmic fluorescence also varied in amount and distribution. It was often localized as fluorescent granula and inclusion body like formations around the enlarged nucleus (Fig. 2). In some neurons small fluorescent particles could be distinguished along the axons.

The specificity of the staining was demonstrated serologically 


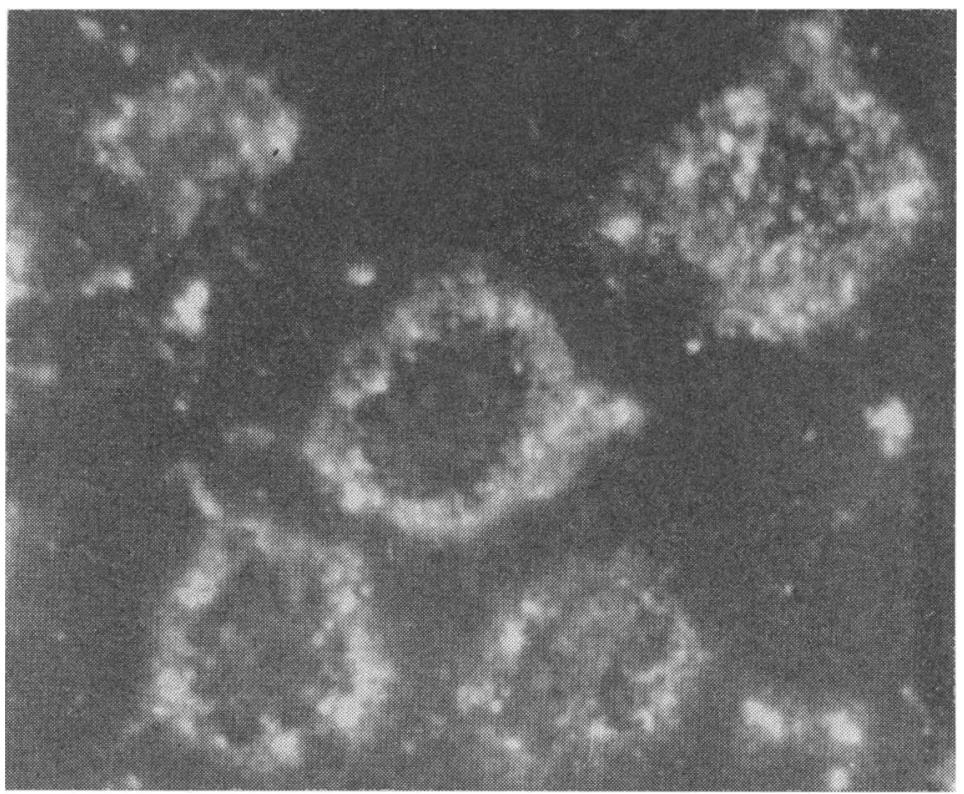

F i g u re 2. Same as Fig. 1. Fluorescent granula in the nucleus and the cytoplasm of the infected neurons. Darkground $\times 1550$.

by inhibition. The conjugate was diluted in unconjugated pseudorabies antiserum and applied to the preparations. Infected neurons showed marked inhibition of fluorescence. The absorption of the conjugate with lyophilized pig kidney powder was sufficient to eliminate the nonspecific staining components from the conjugate. The tissue autofluorescence was blue or greenish brown depending upon the filter combination in use, and it contrasted well with the bright green fluorescence of the infected neurons.

Table 1 gives the results of the examination by immunofluorescence and by rabbit and tissue culture inoculation of 51 piglets. Pseudorabies virus was demonstrated in the brains of 23 pigs, and in 22 pigs positive staining was found in the neurons in at least one of the sections. In one case (no. 38) pseudorabies virus was demonstrated by tissue culture inoculation while antigen could be demonstrated in only a few ependymal cells in the plexus chorioideus. These were not detected at the first examination but on re-examination of the section after the result of the tissue culture inoculation had become known to the microscopist. 
T a b l e 1. Results of the examination of the brains of 51 piglets for pseudorabies virus by FA, tissue culture and rabbit inoculation.

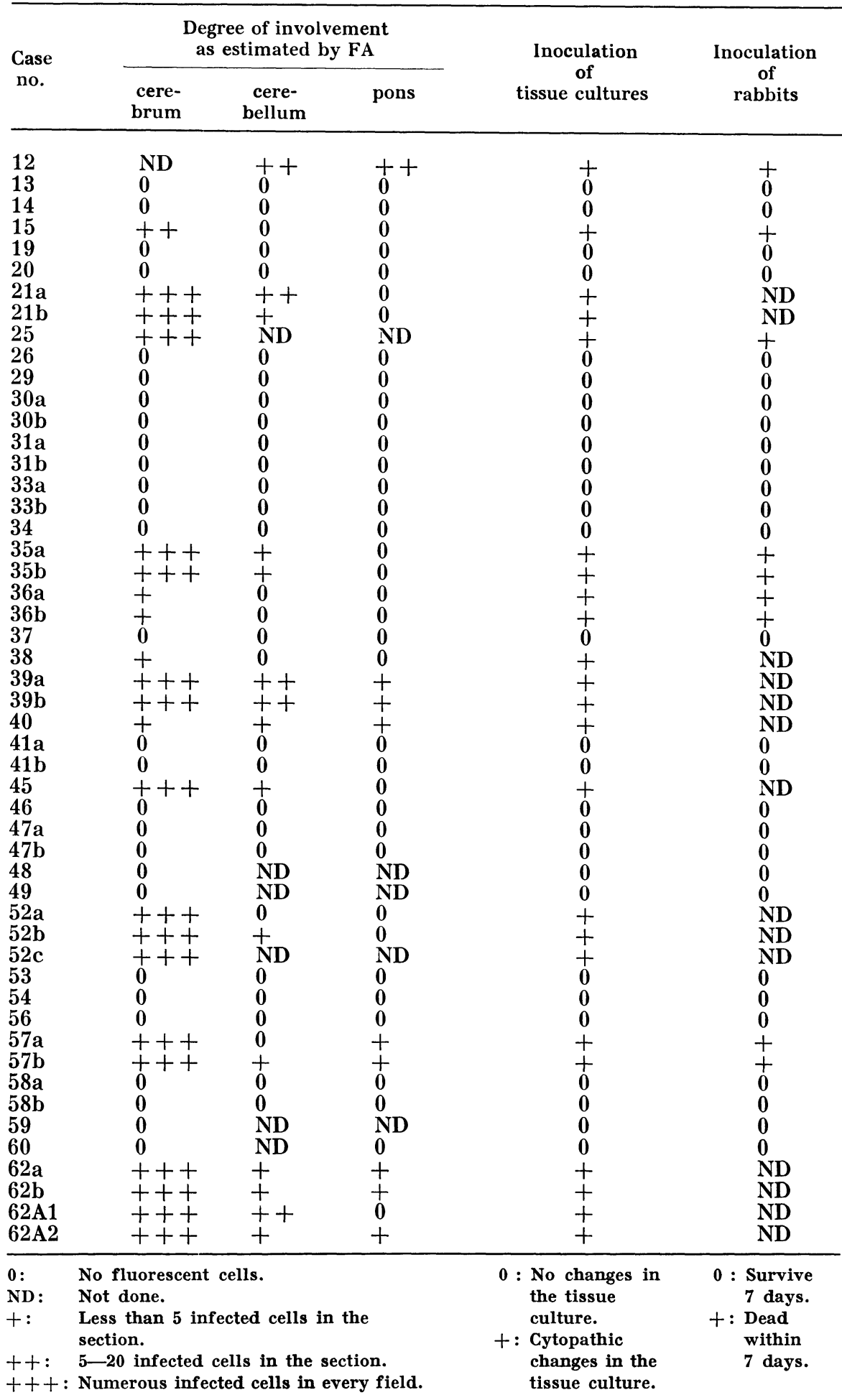




\section{DISCUSSION}

The preliminary results here reported indicate that immunofluorescent staining of frozen sections of brain tissue can be used successfully for the diagnosis of pseudorabies in piglets that have died or been killed after an acute course of disease.

Studies on the distribution of pseudorabies virus in experimentally infected swine (8) as well as pathological and histological investigations (5) have demonstrated that the primary site of viral replication is the mucous membrane of the nasopharyngeal cavity and the upper respiratory tract. The virus may then reach the brain either through the olfactory bulb or the glossopharyngeal nerve. For diagnosis in pigs Mc Ferran \& Dow (8) therefore recommend that tissue samples for viral isolation should include the olfactory bulb and the medulla oblongata.

Because of its soft consistency the olfactory bulb is rather difficult to prepare for freeze-sectioning. It was therefore found more practical to use sections of the cerebrum. The pons or the medulla oblongata may contain virus before any other part of the brain (8), but such cases were not met within this study.

The pathogenetic and diagnostic importance of the tonsils in pseudorabies has recently been investigated by conventional techniques. Characteristic gross and microscopic lesions suggestive of viral replication are frequently seen in this organ in association with this infection, and on titration a higher amount of virus may be found than in the brain $(4,7)$.

In the present study FA staining of sections of the tonsils was made in a few cases. The impression was that although virus was readily isolated from the tonsils the formation of stainable antigen was rather sparse. The fluorescence seen was mostly localized in cellular debris and in desquamated epithelial cells on the surface of the mucous membrane and more rarely in well defined foci. The significance of the staining was difficult to assess, because the low degree of involvement made interpretation of the inhibition test unsafe.

The suitability of tissues other than the brain for both fluorescent antibody staining and viral isolation is being studied in experimentally and naturally infected pigs. The results of these experiments will be given in a subsequent paper.

The conjugates used for this study were of high quality giving a brilliant staining reaction in spite of the low neutralization titer of the unconjugated serum. 
To reduce the possibility of false reactions from unwanted antibodies in the conjugates it might be desirable to produce these from sera of species other than swine. This, however, would require the use of a modified strain of pseudorabies virus, and such a strain was not available to the authors when these investigations were started. When sections of the cerebrum are used this source of error is probably a rather theoretical one, since diagnosis is not based on the presence of fluorescence alone, but also on a distinct immunohistological picture, which is quite characteristic.

The applicability of the immunofluorescent method for diagnosis on post-mortem material is generally limited to fresh specimens. Piglets received at this laboratory will have been dead for $24-48 \mathrm{hrs}$., and only a few have been found unfit for examination by immunofluorescence.

Demonstration of the virus by FA can be accomplished within a few hours, and the results indicate that the method may become a reliable alternative to tissue culture and rabbit inoculation for diagnosis of pseudorabies.

\section{REFERENCES}

1. Albrecht, P., D. Blaskovic, J. Jakubic \& J. Lesso: Demonstration of pseudorabies virus in chick embryo cell cultures and infected animals by the fluorescent antibody technique. Acta virol. 1963, 7, 289-296.

2. Borgen, H. C. \& H. J. Bendixen: Om udbredelsen af pseudorabiesvirusinfektioner blandt kvæg og svin i Danmark. Nord. Vet.Med. 1965, 17, 672-679.

3. Cherry, W. B., M. Goldman \& T. R. Carski: Fluorescent antibody techniques in the diagnosis of communicable diseases. Public Health Service Publication no. 729. United States Government Printing Office, Washington D.C. 1961.

4. Csontos, L.: Determination of virus content, and possible diagnostic value of organs from pigs died of Aujeszky's disease. Acta vet. Acad. Sci. hung. 1966, 16, 219—222.

5. Csontos, L. \& A. Széky: Gross and microscopic lesions in the nasopharynx of pig with Aujeszky's disease. Acta vet. Acad. Sci. hung. 1966, 16, 175-185.

6. Flodin, P.: Dextran Gels and their Applications in Gel Filtration. Thesis. Meijels Bokindustri, Halmstad 1962.

7. Masic, M., M. Excegan \& M. Petrovic: Die Bedeutung der Tonsillen für die Pathogenese und Diagnose der Aujeszkyschen Krankheit bei Schweinen. Zbl. Vet.-Med. 1965, (B), 12, 398-405. 
8. Mc Ferran, J. B. \& C. Dow: The distribution of the virus of Aujeszky's disease (pseudorabies virus) in experimentally infected swine. Amer. J. vet. Res. 1965, 26, 631-635.

9. Pette, J.: Procédés modernes de diagnostic de la Maladie d'Aujeszky. Bull. Off. int. Épiz. 1965, 63, 1835-1851.

\section{SUMMARY}

Fluorescent antibody staining (FA) for pseudorabies has been performed on frozen sections from the cerebrum, cerebellum, and pons from 51 piglets suspected of pseudorabies.

Pseudorabies virus could be demonstrated in the brains of 23 of these pigs both by FA and by rabbit and/or tissue culture inoculation. Most fluorescent cells were found in the cerebral cortex. It is concluded that FA staining may become a reliable alternative to already existing methods for diagnosis of pseudorabies.

\section{ZUSAMMENFASSUNG}

Die Diagnose der Pseudorabies mit fluoreszenzmarkierten Antikörpern.

Kryostatschnitte von Cerebrum, Cerebellum und Pons von 51 Ferkeln, die vermutlich an Pseudorabies gestorben waren, wurden mit fluoreszierenden Antikörpern (FA) gefärbt.

Pseudorabiesvirus wurde sowohl mit FA als auch durch das Impfen von Kaninchen und/oder Gewebekulturen in 23 von diesen nachgewiesen. Die meiste fluoreszierende Cellen wurden in der Grosshirnrinde gefunden.

Die Ergebnisse haben gezeigt, dass die Färbung mit FA eine zuverlässige Methode zum Nachweis von Pseudorabiesvirus anbietet.

\section{SAMMENDRAG}

Diagnose af pseudorabies med fluorescerende antistoffer.

Der er udf $\varnothing r t$ farvning med fluorescerende antistoffer (FA) af kryostatsnit fra cerebrum, cerebellum og pons fra 51 smågrise mistænkt for pseudorabies. Der blev påvist pseudorabiesvirus i 23 af disse grise ved både FA og kanin- og/eller vævskulturpodning. Der fandtes flest fluorescerende celler i cortex cerebri.

Resultaterne viser, at farvning med FA kan anvendes diagnostisk til påvisning af pseudorabies.

(Received August 1, 1967). 